\title{
Microstructure and Mechanical Properties of Ah-36 Steel Weldment Welded using Magnesium Modified E6013 Electrode
}

\author{
Dewin Purnama1 ${ }^{1}$, Winarto Winarto ${ }^{1}{ }^{*}$, Nofrijon Sofyan $^{1}$, Adhi Prihastomo ${ }^{1}$, Kazuhiro Ito ${ }^{2}$ \\ ${ }^{1}$ Department of Metallurgical and Material Engineering, Faculty of Engineering, Universitas Indonesia, \\ Kampus UI Depok, Depok 16424, Indonesia \\ ${ }^{2}$ Joining and Welding Research Institute, Osaka University, 11-1 Mihogaoka, Ibaragi, Osaka 567-0047, Japan
}

\begin{abstract}
The base metal used in this study was high strength low alloy (HSLA) AH-36 steel. The welding process used the E6013 as a rutile electrode. Four rutile electrodes were produced by adding Mg metal powder, ranging from 0 to $5 \mathrm{wt}$.\%, to the initial electrode layer in such a way as to obtain Mn and Si deposits according to ANSI/AWS standard A5.1-91. The shielded metal arc welding (SMAW) method was used with heat inputs of $1.5 \mathrm{~kJ} / \mathrm{mm}$ and $2.5 \mathrm{~kJ} / \mathrm{mm}$. The tensile property, Charpy-V impact, and microhardness tests were performed to measure the mechanical properties of the weld metal. The observation of the metallographic structure was performed using an optical microscope. The results showed that with the increase of Mg layer content, the metal-oxygen level decreased, and the content of $\mathrm{Mn}$ and Si increased. The toughness and tensile strength of AH-36 steel improved, and the optimal Mg content is determined.
\end{abstract}

Keywords: E6013 electrodes; Magnesium; Mechanical properties; Microstructure; SMAW

\section{Introduction}

Rutile base electrodes constitute the largest percentage of the total manual electrodes that have been produced for many years (Surian and de Rissone, 1999). The E6013, E7014 and E7024 rutile base electrodes are the types widely used for welding in atmospheric conditions, especially in shielded metal arc welding (SMAW), because they are suitable for all welding positions and exhibit perfect arc stability, ease of handling, and excellent weld bead appearance (Brziak et al., 2011). E7014 and E7024 are mostly used in high strength steel welding, but they are costly, and their availability in the market is limited (Winarto et al., 2018). Another type of electrode that is easily found in the market and costs less than other rutile-based electrodes is the E6013 electrode. However, this type of electrode is rarely used for high strength structural applications because the mechanical properties of the weldment resulting from this type of electrode are poor (De Rissone et al., 2002).

Many efforts have been made by investigators to increase the mechanical properties of the resulting weldment of this electrode. The minimum tensile strength of the E6013 wire is around $410 \mathrm{MPa}$, much lower than that of the E7024 electrode, and based on previous research (Winarto et al., 2018), the performance of the E6013 electrode can be improved in toughness. It has been found that the E6013 electrode can increase the toughness of all incorporation of a strong deoxidant such as $\mathrm{Mg}$ powder and $\mathrm{Ti}$ as a coating to produce lower 
oxygen levels (Surian, 1997; De Rissone et al., 2001). Other investigators (Boniszewski and Evans, 1995a) found that adding elements of $\mathrm{Mg}$ and $\mathrm{Ti}$ cause a change in the microstructure evolution and an increase in the toughness properties in the HAZ and weld metal regions. Further, they found that the addition of $\mathrm{Mg}$ elements required that that $\mathrm{Si}$ content in the weld metal should be kept below a specific value to ensure proper weld toughness (Boniszewski and Evans, 1995a, 1995b). The development of research on the addition of Mg to the rutile-based electrode E7024 has been carried out by Surian (1997), who has found that increasing $\mathrm{MgO}$ content in the slag resulted in increasing impact resistance and reduced diffusible hydrogen content in the weld metal.

Manufacturers of consumable welding produce more coated rutile electrodes than the usual basic rutile electrodes because the former technically better (Surian, 1997). Besides, rutile electrodes are employed when joining using the SMAW. Because of that, and due to its low cost and straightforward operation, this electrode is in high demand (Ibarra et al., 1989).

As such, the aim of this investigation is to determine the operating characteristics of diffused electrodes and hydrogen from deposited metals. The reason for choosing $\mathrm{Mg}$ powder is that it can reduce the oxygen content in the weld deposits (Evans, 1980; Kotecki, 2000) that is transferred to slag and increases its basicity, and thus will improve its weldment mechanical properties. Chi et al. (Feng et al., 2009) reported that the Mg addition would refine the microstructure of the coarse grain in the heat-affected zone (CG-HAZ) and increase the impact toughness of low carbon steel through the mechanism of $\mathrm{MgO}$ formation. Furthermore, they also explained that the Ti-Mg-O oxide compound has a strong potential to initiate nucleation of an acicular ferrite (AF). Zhu and Yang (2011) likewise found that $\mathrm{Mg}$ could increase the ratio of AF crystals appearing at large angle boundaries to each other in the $\mathrm{HAZ}$ of low carbon steels. Additionally, $\mathrm{MgO}-\mathrm{MnS}$ and $\mathrm{MgO}-\mathrm{Al}_{2} \mathrm{O}_{3}-\mathrm{MnS}$ are the most effective complex inclusions to start the nucleation of AFs (Lin et al., 2018).

\section{Experimental Methods}

\subsection{Materials}

An AH-36 steel plate was used in the SMAW process. Table 1, below, exhibits the chemical composition of the parent material. Based on the calculation of the carbon equivalent (CE) formula, the $\mathrm{CE}$ value of the $\mathrm{AH}-36$ steel plate is 0.212 . Figure 1 a shows the specimen steel plate with a $45^{\circ} \mathrm{V}$-groove and dimensions of $200 \times 150 \times 10 \mathrm{~mm}$. The backing plate was used for root opening $2 \mathrm{~mm}$. Figure $1 \mathrm{~b}$ shows the welding process specimen was carried out in five passes: the first in the root area by a $2.5 \mathrm{~mm}$ diameter electrode followed by filler pass (3.2 $\mathrm{mm}$ diameter electrode) and equipped with a capping pass as shown in Figure 1b.

Table 1 The chemical composition of AH-36 steel plate

\begin{tabular}{ccccccccccc}
\hline \multicolumn{10}{c}{ Elements (wt. \%) } \\
\hline $\mathrm{C}$ & $\mathrm{Si}$ & $\mathrm{Mn}$ & $\mathrm{P}$ & $\mathrm{S}$ & $\mathrm{Al}$ & $\mathrm{Nb}$ & $\mathrm{V}$ & $\mathrm{Ti}$ & $\mathrm{CE}^{\mathrm{a}}$ \\
0.058 & 0.193 & 0.870 & 0.012 & 0.001 & 0.033 & 0.038 & 0.030 & 0.010 & 0.212 \\
\hline
\end{tabular}

a The CE formula: $\% \mathrm{C}+\% \mathrm{Mn} / 6+\%(\mathrm{Cr}+\mathrm{V}) / 5+\%(\mathrm{Ni}+\mathrm{Nb}+\mathrm{Ti}) / 15$

\subsection{Electrodes}

The eight types of rutile-grade electrodes have been prepared in this work. The design of the electrodes is presented in Table 2. Low carbon steel core rods with $3.2 \mathrm{~mm}$ and 2.5 mm diameter electrodes were used. 


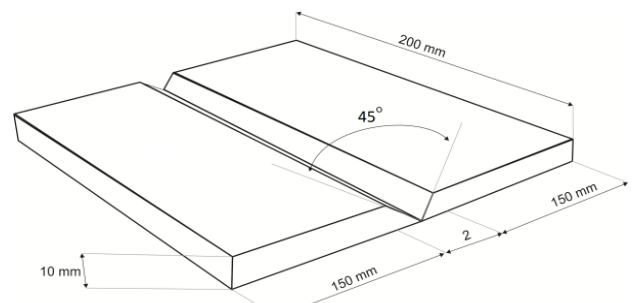

(a)

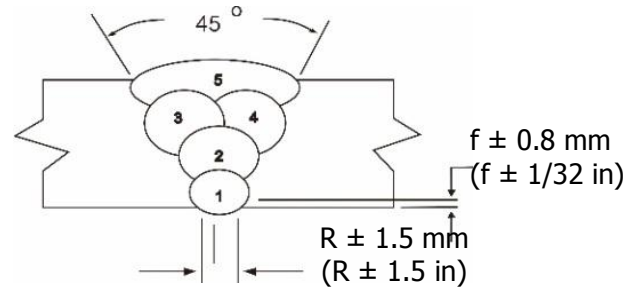

(b)

Figure 1 Joint design of welded sample with (a) single V-groove and (b) number of passes

Table 2 Design of the electrodes

\begin{tabular}{cccc}
\hline No. & $\begin{array}{c}\text { Specimen } \\
\text { code }\end{array}$ & $\begin{array}{c}\text { Heat Input } \\
(\mathrm{kJ} / \mathrm{mm})\end{array}$ & $\begin{array}{c}\text { Magnesium } \\
\text { content (wt.\%) }\end{array}$ \\
\hline 1 & $\mathrm{~A} 1$ & 1.5 & 0 \\
2 & $\mathrm{~A} 2$ & 1.5 & 1 \\
3 & $\mathrm{~A} 3$ & 1.5 & 3 \\
4 & $\mathrm{~A} 4$ & 1.5 & 5 \\
5 & $\mathrm{~B} 1$ & 2.5 & 0 \\
6 & $\mathrm{~B} 2$ & 2.5 & 1 \\
7 & $\mathrm{~B} 3$ & 2.5 & 3 \\
8 & $\mathrm{~B} 4$ & 2.5 & 5 \\
\hline
\end{tabular}

The Mg powder used to cover the electrode flux was first weighed (as shown in Table 2) and then mixed into a varnishing solution. The mixture was then applied to the electrode by brushing. The experimental electrodes were waterproofed with commercial varnish and dried at room temperature for 24 hours. After the rest of the flux moisture was removed, the electrodes were heated to $100^{\circ} \mathrm{C}$ for two hours.

\subsection{Welding Parameters}

The SMAW process method was used with the E6013 electrode as filler metal; this was modified by adding $0,1,3$, and $5 \mathrm{wt} . \% \mathrm{Mg}$. Table 3 presents the welding parameters. The filler was 6013 class with direct current electrode positive (DCEP) polarity and potential difference of 25-26 volts.

Table 3 Welding parameters

\begin{tabular}{ccccccc}
\hline Weld Pass & Dia. $(\mathrm{mm})$ & $\begin{array}{c}\text { Current Type } \\
\text { and Polarity }\end{array}$ & $\begin{array}{c}\text { Ampere } \\
(\mathrm{A})\end{array}$ & $\begin{array}{c}\text { Volts } \\
(\mathrm{V})\end{array}$ & $\begin{array}{c}\text { Travel } \\
\text { Speed } \\
(\mathrm{mm} / \mathrm{min} .)\end{array}$ & $\begin{array}{c}\text { Heat Input } \\
(\mathrm{kJ} / \mathrm{mm})\end{array}$ \\
\hline Root & 2.5 & DCEP (DC+) & $85-95$ & $25-26$ & 100 & 1.5 \\
Root & 2.5 & DCEP (DC+) & $85-95$ & $25-26$ & 60 & 2.5 \\
Filler & 3.2 & DCEP (DC+) & $110-130$ & $25-26$ & 130 & 1.5 \\
Filler & 3.2 & DCEP (DC+) & $110-130$ & $25-26$ & 70 & 2.5 \\
\hline
\end{tabular}

\subsection{Mechanical Testing}

The transverse tensile, Charpy impact and Vickers microhardness tests were carried out to evaluate the mechanical properties of AH-36 steel welded at room temperature. The tensile and impact test specimens are illustrated in Figures $2 \mathrm{a}$ and $2 \mathrm{~b}$. The universal testing machine (Tensilon RTF-2410, Japan) with a speed of $6 \mathrm{~mm} / \mathrm{min}$ was used in this experiment. In the mechanical property tests, each data point represented an average of at 
least two to three specimens. Vickers microhardness was measured across the welded joints with a load of $300 \mathrm{gf}$ for 10 seconds using the testing machine (MicroMet 5100 series) with standard ASTM E384 (Muzakki et al., 2018).

\subsection{Metallography and Non-destructive Testing}

The microstructures of the weld metal, HAZ, and base metals were observed using a microscope optic (Zeiss Primo Star, Germany). The specimens were grounded with 1500grit emery papers, polished using a diamond paste, and etched with a 3\% nitric acid solution (Baskoro et al., 2017). The elemental composition of the weld metal and slag were analyzed using energy dispersive spectroscopy (EDS). The fracture surfaces of the impact test welded joints were also examined using a scanning electron microscope (EVO MA10, Zeiss). A penetrant test (PT) and a radiographic test (RT) were carried out to investigate weld defects.

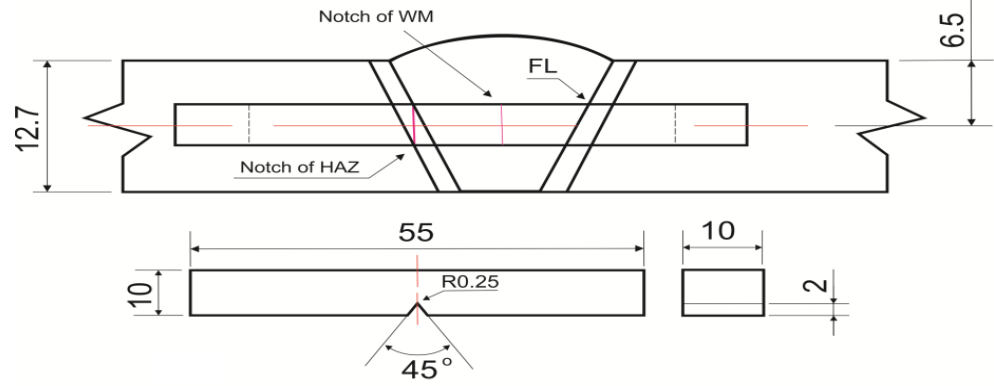

(a)

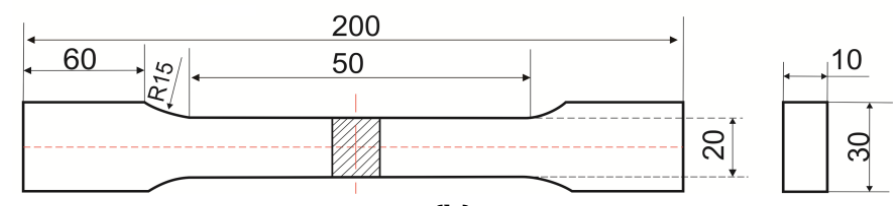

(b)

Figure 2 The dimensions of the specimen test: (a) schematic of the Charpy impact specimens; (b) schematic of the tensile specimens

\section{Results and Discussion}

\subsection{PT and RT of Welds}

In this study, some process welding results were compared, and all-welded samples were inspected using a dye PT and RT, as shown in Figure 3. The welding process using the E6013 electrode with the addition of 0, 1, 3, and 5 wt.\% Mg content produced good visual results.

The welded plate with the addition of $1 \mathrm{wt} . \% \mathrm{Mg}$ shows the porosity and undercut, but the addition of $\mathrm{Mg}$ reduced the defects on the weld surface. The addition of Mg causes reduced oxygen levels in the weld metal and increases the Mn content. An increase in the number of Mn elements will reduce porosity, as reported by Rowe et al. (1999).

\subsection{Chemical Composition and Microstructures}

\subsubsection{Chemical analysis}

The results of chemical compositions of weld metal and slag using different $\mathrm{Mg}$ contents in the covering electrode are shown in Table 4 and Table 5, respectively. The composition in weld metal and slag was obtained from welding using modified electrodes with an additional wt.\% Mg. 


\section{DYE PENETRANT TEST (PT)}

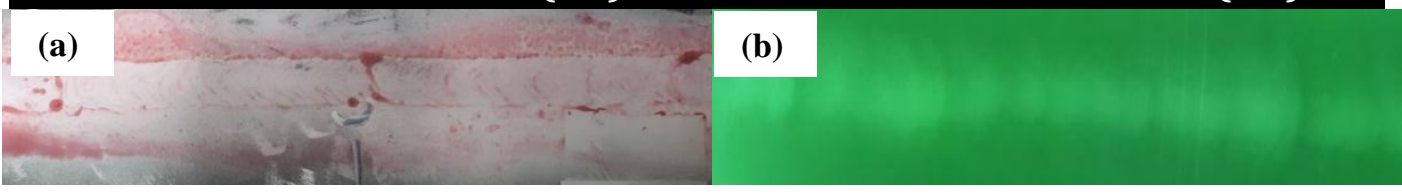

(c)
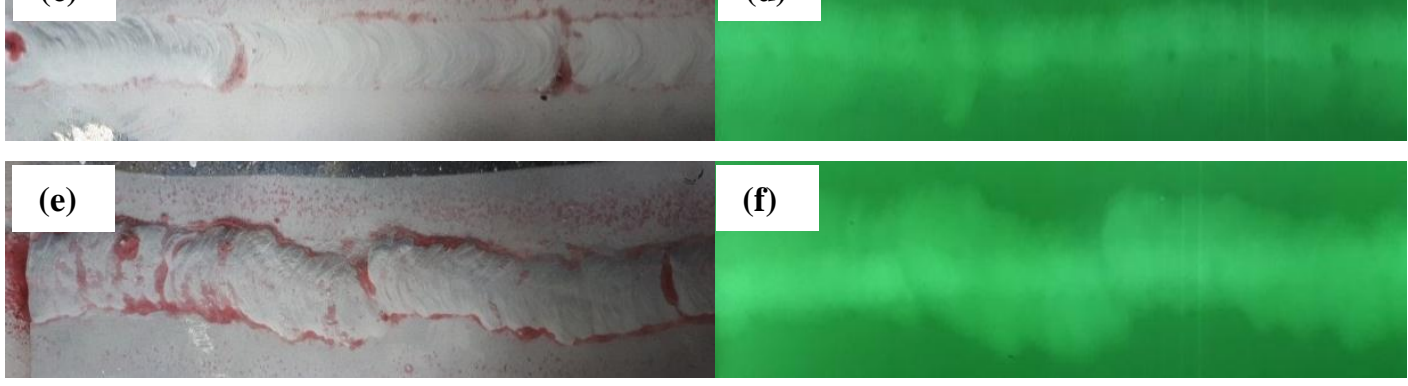

(d)

Figure 3 Penetrant and radiographic tests of weldments produced by atmospheric welding using (a, b) 1 wt.\% Mg, (c, d) 3 wt.\% Mg, (e, f) 5 wt.\% Mg

Table 4 shows that the addition of Mg increased the levels of $\mathrm{Si}$ and $\mathrm{Mn}$ content in the weld metal. The increase in Mn levels in the weld metal increased weld toughness, while the increase in Si levels increased the tensile strength of the welds. Boniszewski and Evans reported that the most important consideration with the addition of $\mathrm{Mg}$ elements would be to keep the Mn content in the weld metal below a specific value to ensure proper weld toughness (Boniszewski and Evans, 1995a, 1995b). Kandavel explained that the Fe atom in $\mathrm{C}$-Fe could be replaced by the addition of $\mathrm{Cr}, \mathrm{Ni}, \mathrm{Si}$, and $\mathrm{Mn}$ as the alloying elements, which reduce the lattice distortion and increase the lattice constant. Subsequently, the strength of weld metal will be increased (Kandavel et al., 2012).

Table 4 Chemical composition of all weld metal at $\mathrm{HI}=2.5 \mathrm{~kJ} / \mathrm{mm}$

\begin{tabular}{cccccc}
\hline \multirow{2}{*}{ Joint No. } & \multicolumn{5}{c}{ Elements (wt. \%) } \\
\cline { 2 - 6 } & $\mathrm{Fe}$ & $\mathrm{C}$ & $\mathrm{Mn}$ & $\mathrm{Si}$ & $\mathrm{Mg}$ \\
\hline B1 & 83.77 & 7.45 & 0.40 & 0.53 & 0.08 \\
B2 & 61.12 & 7.37 & 0.70 & 0.46 & 0.06 \\
B3 & 59.45 & 7.22 & 0.68 & 0.52 & 0.02 \\
B4 & 70.14 & 10.96 & 0.72 & 0.57 & 0 \\
\hline
\end{tabular}

Magnesium added to the E6013 electrode prevents Mn and Si elements from reacting with oxygen to form oxides in the weld metal. Mg almost entirely migrates to the slag to form oxides, as demonstrated in Table 5. Decreasing oxygen content reduced the formation of defects in the form of porosity in the weld metal. The Mg additions to the coating decreased the oxygen content in the deposited metal and increased the weld toughness.

The results of this study are consistent with the results of experiments conducted by Surian (1997), which showed that the addition of 0, 2, and 4 wt.\% Mg to the E7024 electrode using the SMAW method in atmospheric welding results in increased MgO content in the slag, increased impact toughness of the weld, and decreased diffusible hydrogen content in the weld metal.

As demonstrated in Table 5, the calculation of the basicity index (BI) shows that the chemical composition of the slag at a heat input (HI) of $2.5 \mathrm{~kJ} / \mathrm{mm}$ is acid, and of the specimens with 1 to 5 wt.\% Mg added (specimen codes B2 to B4) specimen B3 has the highest BI. A higher BI indicates that the oxygen content in the weld metal will be decreased, 
and the tensile strength in the weld metal will be increased, as shown in Figure 6 (Datta and Parekh, 1989).

Table 5 Chemical composition of slag at $\mathrm{HI}=2.5 \mathrm{~kJ} / \mathrm{mm}$

\begin{tabular}{cccccccccccc}
\hline \multirow{2}{*}{$\begin{array}{c}\text { Specimen } \\
\text { code }\end{array}$} & \multicolumn{1}{c}{ Fe } & $\mathrm{C}$ & $\mathrm{O}$ & $\mathrm{Si}$ & $\mathrm{Mg}$ & $\mathrm{Na}$ & $\mathrm{Al}$ & $\mathrm{K}$ & $\mathrm{Ca}$ & $\mathrm{Ti}$ & $\mathrm{BI}$ \\
\hline $\mathrm{B} 1$ & 11.90 & 3.56 & 39.60 & 10.70 & 0.19 & 1.84 & 1.46 & 4.85 & 4.01 & 15 & 0.886 \\
$\mathrm{~B} 2$ & 3.74 & 3.44 & 43.00 & 13.20 & 1.05 & 1.53 & 4.68 & 2.31 & 3.69 & 23 & 0.384 \\
$\mathrm{~B} 3$ & 1.77 & 3.09 & 43.80 & 10.90 & 4.56 & 1.53 & 3.88 & 2.32 & 2.69 & 25 & 0.470 \\
$\mathrm{~B} 4$ & 0.61 & 1.98 & 43.80 & 3.87 & 5.64 & 1.59 & 3.42 & 0.86 & 1.08 & 37 & 0.396 \\
\hline
\end{tabular}

(a)Basicity index calculated according to Tuliani's formula

\subsubsection{Microstructure analysis}

The weld metal microstructures of samples with an $\mathrm{HI}$ of $1.5 \mathrm{~kJ} / \mathrm{mm}(\mathrm{A} 1, \mathrm{~A} 2, \mathrm{~A} 3, \mathrm{~A} 4)$ and an HI of $2.5 \mathrm{~kJ} / \mathrm{mm}$ (B1, B2, B3, B4) are shown in Figures 4 and 5, respectively. The microstructure of weld metal A1 (sample with an $\mathrm{HI}$ of $1.5 \mathrm{~kJ} / \mathrm{mm}$ and $0 \mathrm{wt} . \% \mathrm{Mg}$ ) shows pure ferrite (PF), side plate ferrite (SPF), and grain boundary ferrite (GBF), as shown in Figure 4a. AF was present in weld metal A2, where $1 \mathrm{wt} . \% \mathrm{Mg}$ was added (Figure $4 \mathrm{~b}$ ). The $\mathrm{AF}$ increased, and lath martensite was present when the Mg content was increased up to 3 wt.\% (Figure 4c). With the increasing addition of $\mathrm{Mg}$, the average width of columnar grains from decreased specimen A1 to A4. In the specimen of A1, the number of SPFs is not dominant, but in the A2 and A3 samples, the amount of SPF has increased, whereas, in the A4 sample, it has decreased slightly. The results quantified by the volume fraction can be seen in Table 6. An expansion in AF in the microstructure results in increased tensile strength, excellent impact toughness, and just as excellent weldability (Shao et al., 2018).

Figure 5a shows a microstructure in the weld metal with an $\mathrm{HI}$ of $2.5 \mathrm{~kJ} / \mathrm{mm}$ of specimens without additional $\mathrm{Mg}$, which almost resembled the microstructure of $\mathrm{A} 1$. With a further increase in $\mathrm{Mg}$ content from $1 \mathrm{wt} \% \%$ to $5 \mathrm{wt} . \%$, the AF grown on the columnar grain in the weld metal increased, as shown in Figures $5 b, 5 c$, and $5 d$. The microstructure showed the full lath martensite, as seen in Figure $5 \mathrm{~d}$.

The metallographic analysis shows that the increased Mg content in electrode coatings can be refined and reduce non-metal inclusions be fewer and smaller in the recrystallization structure of the Charpy- $\mathrm{V}$ test results, as reported by Abson. These factors will contribute to increasing toughness (Abson \& Pargeter, 1987).

Figures 6 and 7 show the SEM-EDS analysis of weldment on weld metal with an HI of $2.5 \mathrm{~kJ} / \mathrm{mm}$. These figures confirm the chemical composition presented in Table 4.

Table 6 Level of different microstructural constituents in columnar locales

\begin{tabular}{ccccc}
\hline $\begin{array}{c}\text { Specimen } \\
\text { code }\end{array}$ & AF & SPF & PF & GBF \\
\hline A1 & 0 & 18.3 & 25.4 & 56.3 \\
A2 & 1.3 & 28.2 & 21.3 & 49.2 \\
A3 & 3.5 & 41.3 & 16.1 & 39.1 \\
A4 & 2.6 & 39.4 & 15.5 & 42.5 \\
\hline \multicolumn{2}{c}{ AF: acicular ferrite } & \multicolumn{3}{c}{ PF: polygonal ferrite } \\
SPF: side plate ferrite & \multicolumn{2}{c}{ GBF: grain boundary ferrite }
\end{tabular}



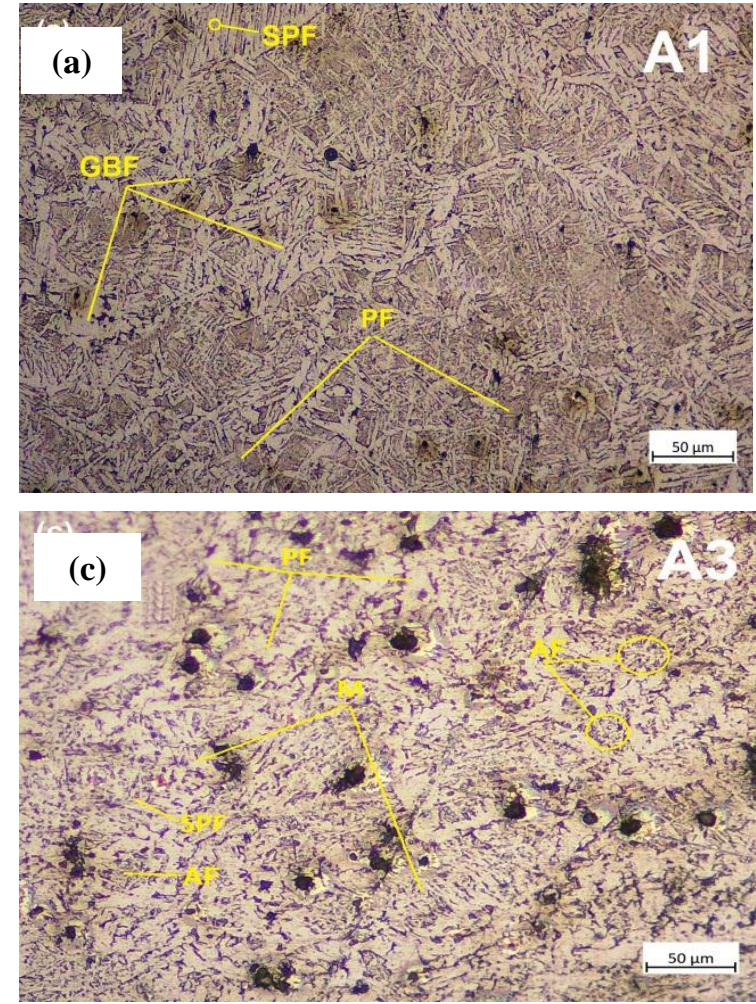
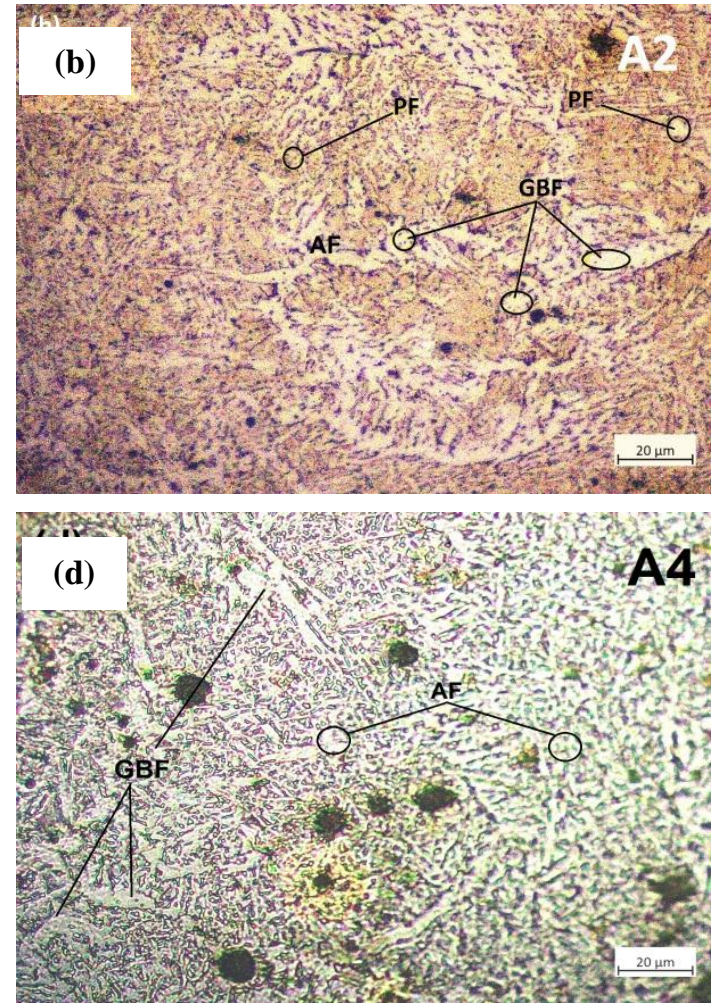

Figure 4 The columnar microstructures in weld metal at $\mathrm{HI}=1.5 \mathrm{~kJ} / \mathrm{mm}$ : (a) A1, (b) A2, (c) A3, (d) A4
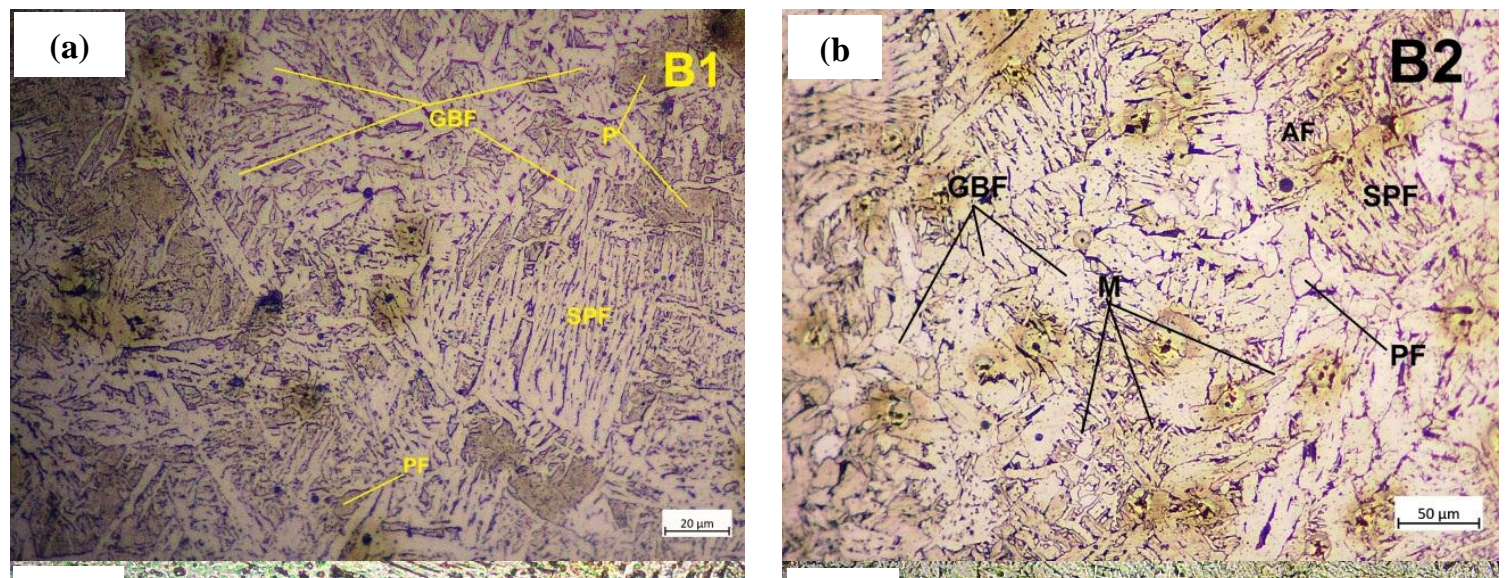

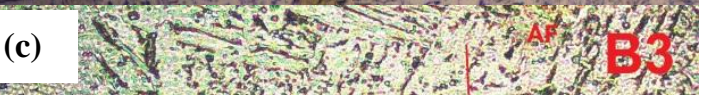

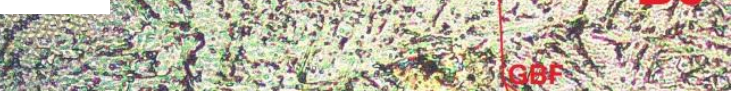

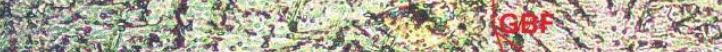

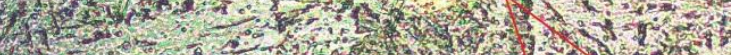

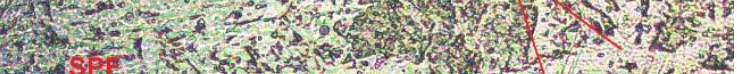

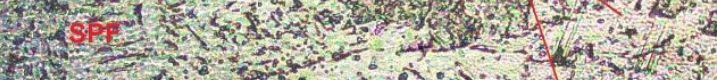

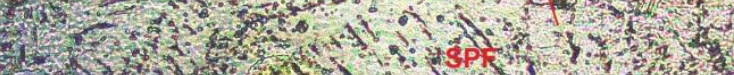

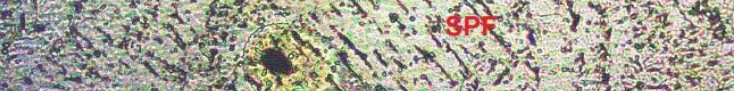

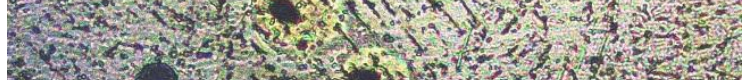

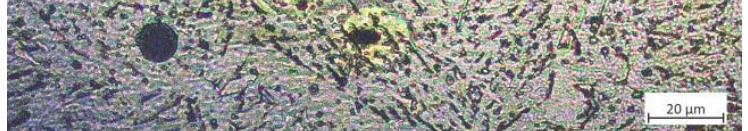

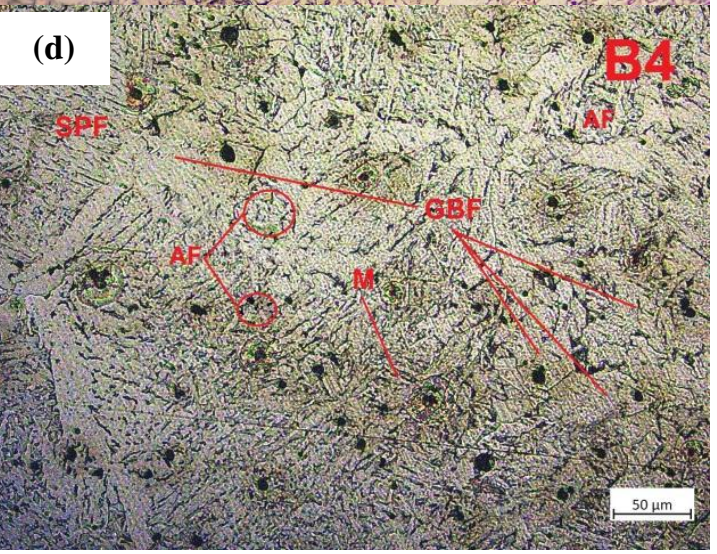

Figure 5 The columnar microstructures in weld metal at $\mathrm{HI}=2.5 \mathrm{~kJ} / \mathrm{mm}$ : (a) B1, (b) B2, (c) B3, (d) B4 

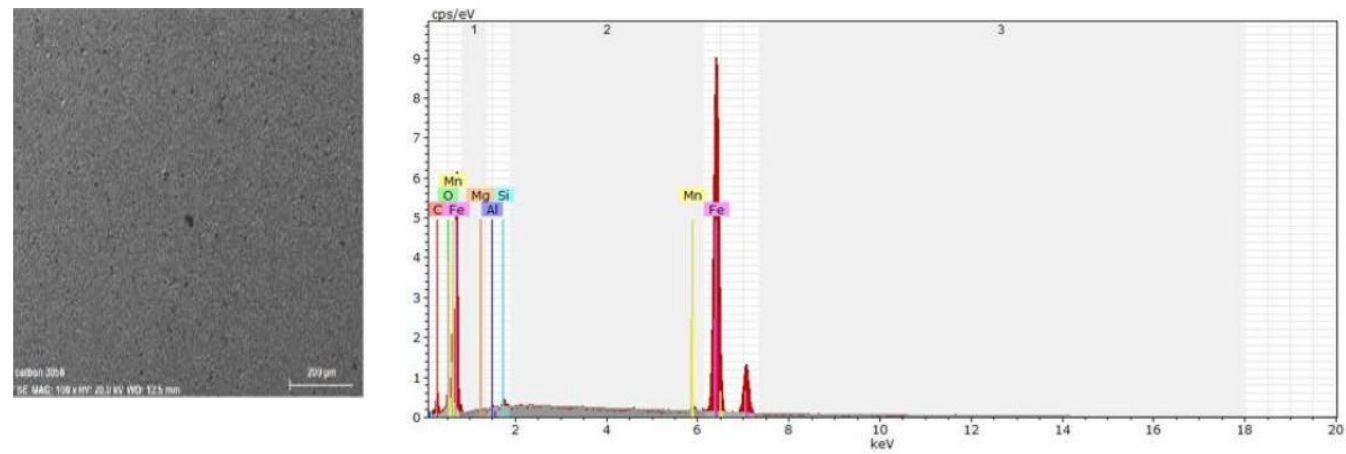

\begin{tabular}{lccccc}
\hline \multirow{2}{*}{ Element } & \multirow{2}{*}{ Series } & unn. C & norm. C & Atom. C & Error (1 Sigma) \\
\cline { 2 - 6 } & & {$[\mathrm{wt} . \%]$} & {$[\mathrm{wt} . \%]$} & {$[\mathrm{wt} . \%]$} & [wt.\%] \\
\hline Carbon & K-series & 7.37 & 9.22 & 29.77 & 2.15 \\
\hline Oxygen & K-series & 3.00 & 3.74 & 9.08 & 0.85 \\
\hline Aluminium & K-series & 0.25 & 0.31 & 0.44 & 0.06 \\
\hline Silicon & K-series & 0.46 & 0.57 & 0.79 & 0.07 \\
\hline Iron & K-series & 68.17 & 85.21 & 59.18 & 1.91 \\
\hline Manganese & K-series & 0.70 & 0.87 & 0.62 & 0.08 \\
\hline Magnesium & K-series & 0.06 & 0.08 & 0.13 & 0.04 \\
\hline & Total: & 80.01 & 100.00 & 100.00 &
\end{tabular}

Figure 6 SEM-EDS analysis of specimen B2 (HI = $2.5 \mathrm{~kJ} / \mathrm{mm} ; 1 \mathrm{wt} . \% \mathrm{Mg})$
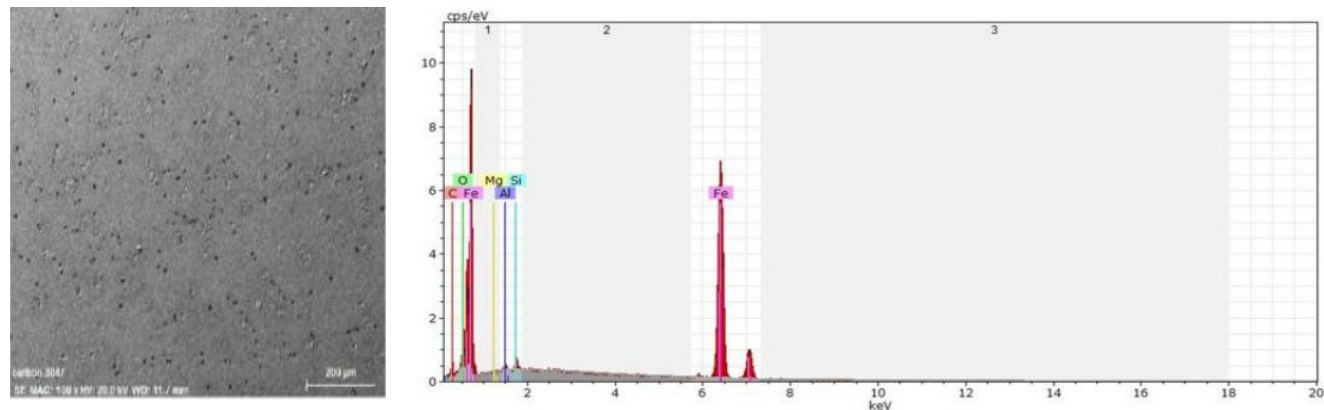

\begin{tabular}{lccccc}
\hline \multirow{2}{*}{ Element } & \multirow{2}{*}{ Series } & unn. C & norm. C & Atom. C & Error (1 Sigma) \\
\cline { 3 - 6 } & & {$[\mathrm{wt} . \%]$} & {$[\mathrm{wt} . \%]$} & {$[\mathrm{wt} . \%]$} & {$[\mathrm{wt} . \%]$} \\
\hline Carbon & K-series & 7.22 & 10.00 & 29.22 & 2.24 \\
\hline Oxygen & K-series & 6.21 & 8.60 & 18.86 & 1.47 \\
\hline Aluminium & K-series & 0.32 & 0.45 & 0.58 & 0.06 \\
\hline Silicon & K-series & 0.52 & 0.72 & 0.90 & 0.07 \\
\hline Iron & K-series & 57.93 & 80.21 & 50.40 & 1.66 \\
\hline Magnesium & K-series & 0.02 & 0.03 & 0.04 & 0.01 \\
\hline & Total: & 72.22 & 100.00 & 100.00 &
\end{tabular}

Figure 7 SEM-EDS analysis of specimen B3 (HI = $2.5 \mathrm{~kJ} / \mathrm{mm}$; $3 \mathrm{wt} . \% \mathrm{Mg})$

\subsection{Mechanical Properties}

The mechanical properties of A1-A4 and B1-B4 weld metal specimens were measured. The microhardness, tensile strength, and impact toughness (COD) at room temperature were calculated. SEM and EDS were used to test the fracture surface.

\subsubsection{Tensile properties, ductility, and toughness}

The tensile test results for atmospheric welded joints with the different Mg additions are presented in Figure 8, and the testing was conducted at room temperature. The average ultimate tensile strength at an $\mathrm{HI}$ of $1.5 \mathrm{~kJ} / \mathrm{mm}$ is $520 \mathrm{MPa}$, and $541 \mathrm{MPa}$ at an $\mathrm{HI}$ of 2.5 $\mathrm{kJ} / \mathrm{mm}$. The highest ultimate tensile strength at an $\mathrm{HI}$ of $1.5 \mathrm{~kJ} / \mathrm{mm}$ was obtained with the addition of 3 wt.\% Mg (533 MPa), and likewise, the highest tensile strength at the HI of 2.5 
$\mathrm{kJ} / \mathrm{mm}$ was obtained with the addition of $3 \mathrm{wt} . \% \mathrm{Mg}$ (555 MPa). The result of the welding process of the $\mathrm{AH}-36$ steel plate with the $\mathrm{HI}$ of $2.5 \mathrm{~kJ} / \mathrm{mm}$ was a higher tensile strength than with the $\mathrm{HI}$ of $1.5 \mathrm{~kJ} / \mathrm{mm}$.

The tensile test A4 and B1 specimens were fractured in the weld metal, while the others were in the base metal. The necking phenomena of the fracture present in the A3, A4, and B4 specimens exhibit a ductile fracture, while the others presented a brittle fracture.

The welding of the AH-36 plates with the $\mathrm{HI}$ of $2.5 \mathrm{~kJ} / \mathrm{mm}$ and the addition of up to 5 wt.\% Mg caused the Mn content in the weld metal to reach an optimum level of $0.83 \mathrm{wt} . \%$. The highest impact test results obtained were Mn content levels of 1.5 wt.\% (Evans, 1983; Surian and Boniszewski, 1992). Increased Mn content will increase the level of AF in the metal microstructure (Evans, 1983). This AF level can increase the strength and toughness of welding materials with increased $\mathrm{Mn}$.

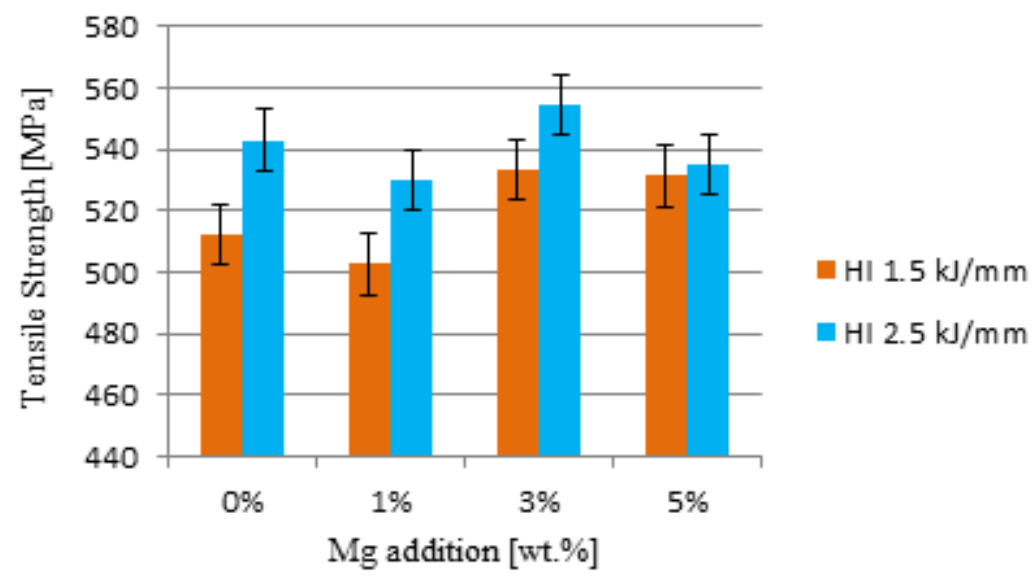

Figure 8 Tensile test results for atmospheric welded joints with different Mg additions

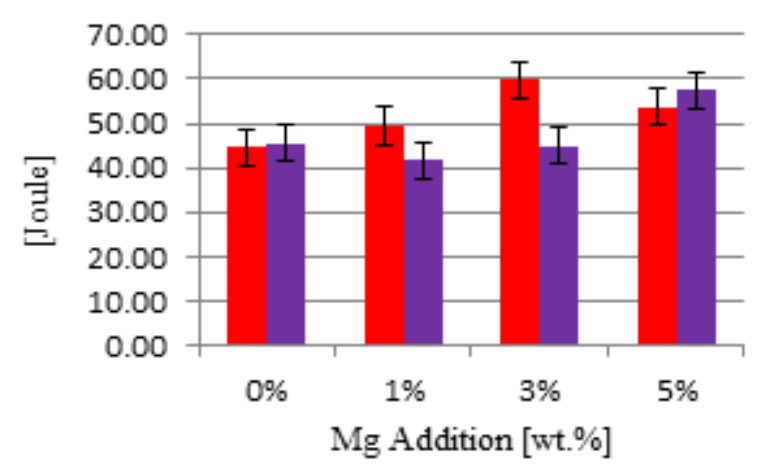

(a)

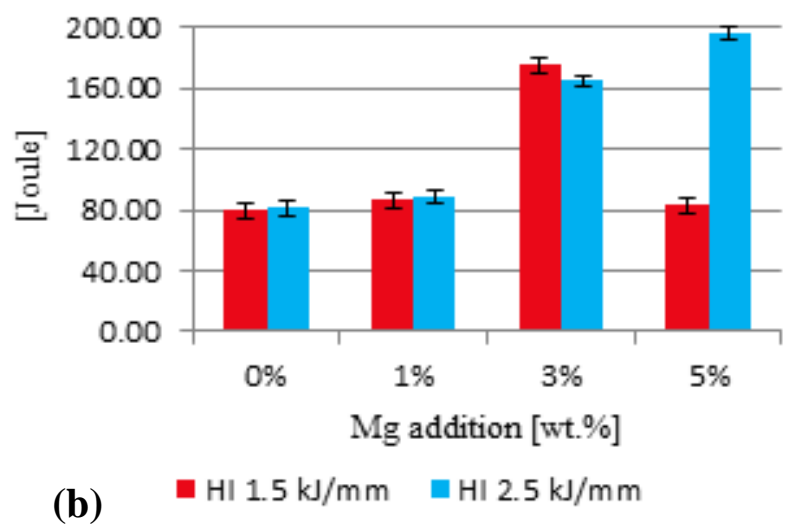

Figure 9 Impact test results for atmospheric welded joints with different Mg additions: (a) weld metal, (b) HAZ

The impact test results are presented in Figure 9. The toughness of the average impact of weld metals at the $\mathrm{HI}$ of $1.5 \mathrm{~kJ} / \mathrm{mm}$ and $2.5 \mathrm{~kJ} / \mathrm{mm}$ is $51.89 \mathrm{~J}$ and $47.4 \mathrm{~J}$, respectively, while the average value of the toughness effect of HAZ at the $\mathrm{HI}$ of $1.5 \mathrm{~kJ} / \mathrm{mm}$ and $2.5 \mathrm{~kJ} / \mathrm{mm}$ is $106 \mathrm{~J}$ and $132.9 \mathrm{~J}$, respectively. At an $\mathrm{HI}$ of $1.5 \mathrm{~kJ} / \mathrm{mm}$, weld toughness was found to increase to the maximum value and then decrease with increasing Mg content in the weld metal. The maximum toughness value at the $\mathrm{HI}$ of $1.5 \mathrm{~kJ} / \mathrm{mm}$ is $59.78 \mathrm{~J}$. This result was obtained by adding $3 \mathrm{wt} . \% \mathrm{Mg}$ and is more than 1.3 times greater than the value obtained from welds without Mg. Meanwhile, at HAZ, the maximum toughness value at room temperature occurs 
for the addition of $3 \mathrm{wt} . \% \mathrm{Mg}(175.22 \mathrm{~J})$. This value is 1.2 times greater than the value before the addition of $\mathrm{Mg}$.

Figure 10 shows the Charpy impact test SEM fractography. In Figure 10a, it can be seen that the appearance of the Charpy test results impacting the fracture surface of the weld metal is filled with dimple parabola of different sizes, indicating significant characteristics of high ductility. Meanwhile, Figure 10b exhibits a lighter color with a characteristic mixture of a large number of cleavages with typical river patterns and several microvoids; this shows the characteristics of a brittle fracture.
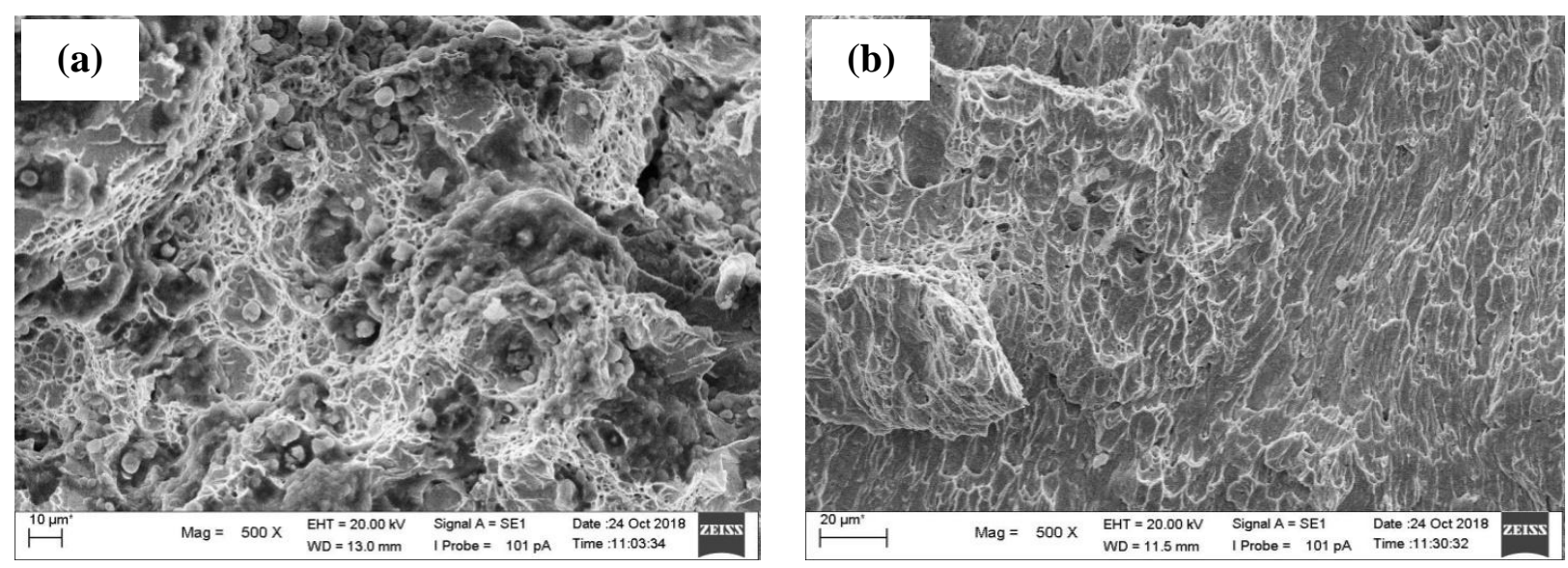

Figure 10 Secondary electron image of Charpy impact fractography: (a) weld metal, (b) HAZ

\subsubsection{Hardness}

For each of the eight weldments, the deliberate Vickers hardness technique was employed. This test was carried out with a load of $300 \mathrm{gf}$ for 10 seconds, starting from the centerline to the base metal. Figure 11 shows the hardness distribution data, and the highest hardness values were found at the centerline of the weld metal with an average hardness value of $225.2 \mathrm{HV}_{0.3}$. This value then dropped to the fusion line area with an average hardness value of $181.4 \mathrm{HV}_{0.3}$; then in the $\mathrm{HAZ}$ region, the average value slightly increased by $1.65 \%$ to $184.4 \mathrm{HV}_{0.3}$. Specimen $\mathrm{A} 4$ has the highest average hardness value. The highest hardness value, $280 \mathrm{HV}_{0.3}$, was found in the weld metal. As shown in Figure 11, welding at the $\mathrm{HI}$ of $1.5 \mathrm{~kJ} / \mathrm{mm}$ results in a higher average hardness value than welding at the $\mathrm{HI}$ of $2.5 \mathrm{~kJ} / \mathrm{mm}$.
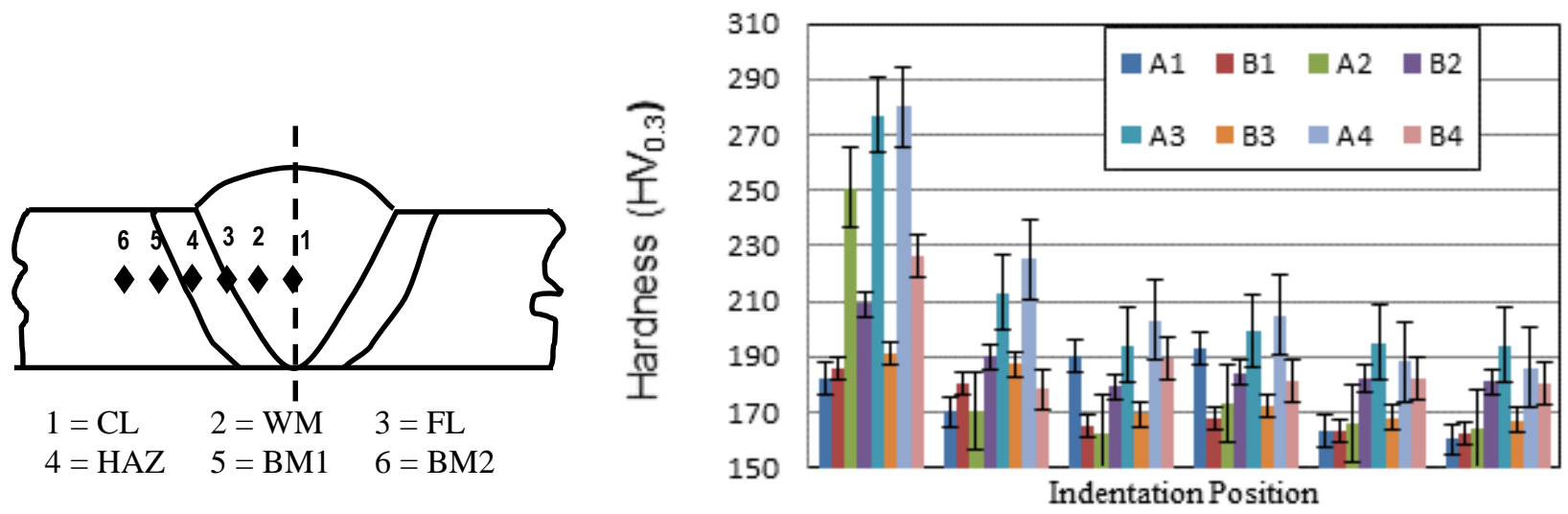

Figure 11 Hardness distribution data

The highest hardness occurred when welding at the $\mathrm{HI}$ of $1.5 \mathrm{~kJ} / \mathrm{mm}$ with the addition of 3-5 wt.\% Mg (specimens A4 and A3). Both specimens exhibited a lath martensite microstructure in their weld metal areas. Conversely, welding at an $\mathrm{HI}$ of $2.5 \mathrm{~kJ} / \mathrm{mm}$ with 
an additional $1 \mathrm{wt} . \% \mathrm{Mg}$ (specimen $\mathrm{B} 2$ ) resulted in a microstructure in the form of GBF and SPF on the grain. In the HAZ region, welding at the $\mathrm{HI}$ of $1.5 \mathrm{~kJ} / \mathrm{mm}$ produces a slightly higher hardness value than welding at the HI of $2.5 \mathrm{~kJ} / \mathrm{mm}$. This is because welding at the $\mathrm{HI}$ of $1.5 \mathrm{~kJ} / \mathrm{mm}$ (specimens A1-A4) produces less coarse grain near the fusion zones than welding at the $\mathrm{HI}$ of $2.5 \mathrm{~kJ} / \mathrm{mm}$.

\section{Conclusions}

The addition of $\mathrm{Mg}$ content from 1 to 3 wt.\% into the E6013 modified electrodes increased the elemental content of $\mathrm{Mn}$ and $\mathrm{Si}$ and reduced the oxygen levels in the weld metal. The presence of AF was increased in the weld metal. The tensile properties and toughness of AH-36 welds improved by the additional $\mathrm{Mg}$ up to 3 wt.\% into the E6013 modified electrodes using the SMAW process. The addition of Mg also improved the tensile properties and toughness of AH-36 when the weld HI was increased. However, the hardness value in the weld metal was reduced when the HI increased.

\section{Acknowledgments}

The authors would like to acknowledge the Directorate of Research and Public Services, Universitas Indonesia (DRPM-UI), for the financial support for this study through the TADOK Research Grant in 2018.

\section{References}

Abson, D., Pargeter, R., 1987. Factors Influencing the As-deposited Strength, Microstructure, and Toughness of Manual Arc Welds Suitable for C-Mn Steel Fabrication. International Metal Review, Volume 31(1), pp. 141-196

Baskoro, A.S., Muzakki, H., Kiswanto, G., Winarto., 2017. Effects of Micro Resistance Spot Welding Parameters on the Quality of Weld Joints on Aluminum Thin Plate AA 1100. International Journal of Technology, Volume 8(7), pp. 1306-1313

Boniszewski, T., Evans, G., 1995a. Studies of AWS Rutile Electrodes. Part 2: Changes in Toughness at a Constant Strength. In: IIW Sub-Comm.2A intermediate meeting., At TWI, Cambridge, UK, II-A-940-95 (II-A-1263-95)

Boniszewski, T., Evans, G., 1995b. Studies of AWS Rutile Electrodes. Part 3: Deoxidation with Silicon. In: IIW Sub-Comm.2A intermediate meeting., At TWI, Cambridge, UK, II-A-94895

Brziak, P., Łomozik, M., Mizuno, R., Matsuda, F., 2011. Repair Welding of SQV2A Pressure Vessel Steel by Temper Bead Techniques without Post Welding Heat Treatment. Archives of Metallurgy and Materials, Volume 56(2), pp. 205-216

Datta, I., Parekh, M., 1989. Filler Metal Flux Basicity Determination using the Optical Basicity Index. Welding Journal, Volume 68, pp. 68-74

De Rissone, N., Farias, J., Bott, I.D.S., Surian, E., 2002. ANSI/AWS A5. 1-91 E6013 Rutile Electrodes: The Effect of Calcite. Welding Journal, Volume 81(7), pp. 113-124

De Rissone, N.R., Surian, E., Conde, R., De Vedia, L., 2001. Effect of Slag Variations on ANSI/AWS A5. 1-91 E6013 Electrode Properties: Replacement of TiO2 in Electrode Coating with $\mathrm{MnO}, \mathrm{FeO}, \mathrm{CaO}, \mathrm{MgO}, \mathrm{K}_{2} \mathrm{O}$, or $\mathrm{Na}_{2} \mathrm{O}$. Science and Technology of Welding and Joining, Volume 6(5) pp. 323-29

Evans, G., 1980. Effect of Manganese on the Microstructure and Properties of All-weld-metal Deposits. Welding Journal, Volume 59(3), pp. 67-76

Evans, G., 1983. Effect of Manganese on the Microstructure and Properties of All-WeldMetal Deposits. Weld. Res. Abroad, Volume 19, pp. 2-12 
Feng, C., Yang, C.-f., Hang, S., Zhang, Y.-q., Zhou, X., 2009. Effect of Magnesium on Inclusion Formation in Ti-killed Steels and Microstructural Evolution in Welding Induced Coarse-grained Heat Affected Zone. Journal of Iron and Steel Research, International, Volume 16(1), pp. 69-74

Ibarra, S., Grubbs, C., Olson, D., 1989. Underwater Wet Welding of Higher Strength Offshore Steels. In: Offshore Technology Conference, 1-4 May, Houston, Texas

Kandavel, T., Chandramouli, R., Karthikeyan, P., 2012. Influence of Alloying Elements and Density on Aqueous Corrosion Behaviour of Some Sintered Low Alloy Steels. Materials \& Design, Volume 40, pp. 336-342

Kotecki, D., 2000. A Martensite Boundary on the WRC-1992 Diagram-Part 2: The Effect of Manganese. Welding Journal, Volume 79(12), pp. 346-354

Lin, C.-K., Pan, Y.-C., Su, Y.-H.F., Lin, G.-R., Hwang, W.-S., Kuo, J.-C., 2018. Effects of Mg-Al-OMn-S Inclusion on the Nucleation of Acicular Ferrite in Magnesium-containing LowCarbon Steel. Materials Characterization, Volume 141, pp. 318-327

Muzakki, H., Baskoro, A.S., Kiswanto, G., Winarto, W., 2018. Mechanical Properties of the Micro Resistance Spot Welding of Aluminum Alloy to Stainless Steel with a Zinc Interlayer. International Journal of Technology, Volume 9(4), pp. 686-694

Rowe, M., Liu, S., Reynolds, T., 1999. Development of SMAW Coatings for Underwater Wet Welding at Specific Depth Ranges. In: Proceedings of the 18 Offshore Mechanics and Arctic Engineering Conference, St. John's, Newfoundland, Canada, American Society of Mechanical Engineers

Shao, Y., Liu, C., Yan, Z., Li, H., Liu, Y., 2018. Formation Mechanism and Control Methods of Acicular Ferrite in HSLA Steels: A review. Journal of Materials Science \& Technology, Volume 34(5), pp. 737-744

Surian, E., 1997. ANSI/AWS E7024 SMAW Electrodes: The Effect of Coating Magnesium Additions. Welding Research Supplement, Volume 76, pp. 404-411

Surian, E., Boniszewski, T., 1992. Effect of Manganese and Type of Current on the Properties and Microstructure of All-weld-metal Deposited with E7016-1 Electrodes. Welding Research Supplement, Volume 71, pp. 348-364

Surian, E., de Rissone, N.R., 1999. Relationships between Coating Composition, All Weld Metal Properties, Operational Behaviour, and Diffusible Hydrogen in Weld Metal from Rutile Electrodes of Types ANSI/AWS A5. 1-91 E6013 and E7024. Science and Technology of Welding and Joining, Volume 4(3), pp. 133-142

Winarto, W., Purnama, D., Churniawan, I., 2018. The Effect of Different Rutile Electrodes on Mechanical Properties of Underwater Wet Welded AH-36 Steel Plates. In: AIP Conference Proceedings, AIP Publishing

Zhu, K., Yang, Z., 2011. Effect of Mg Addition on the Ferrite Grain Boundaries Misorientation in HAZ of Low Carbon Steels. Journal of Materials Science \& Technology, Volume 27(3), pp. 252-256 